\title{
Response of the Zygopteran Community (Odonata: Insecta) to Change in Environmental Integrity Driven by Urbanization in Eastern Amazonian Streams
}

\author{
Jhose Paixão Brito ${ }^{1}$, Fernando Geraldo Carvalho ${ }^{1,2, *(\mathbb{D})}$ and Leandro Juen ${ }^{1,2}$ (D) \\ 1 Laboratório de Ecologia e Conservação, Instituto de Ciências Biológicas, Universidade Federal do \\ Pará-UFPA, Rua Augusto Correia, Bairro Guamá, Belém, Pará 66.075-110, Brazil; \\ jhopb03@gmail.com (J.P.B.); leandrojuen@gmail.com (L.J.) \\ 2 Programa de Pós-graduação em Ecologia, Universidade Federal do Pará-UFPA, Rua Augusto Correia, \\ Bairro Guamá, Belém, Pará 66.075-110, Brazil \\ * Correspondence: fernandogeraldocarvalho@gmail.com
}

Citation: Brito, J.P.; Carvalho, F.G.; Juen, L. Response of the Zygopteran Community (Odonata: Insecta) to Change in Environmental Integrity Driven by Urbanization in Eastern Amazonian Streams. Ecologies 2021, 2, 150-163. https://doi.org/10.3390/ ecologies 2010008

Academic Editor: Hidetoshi Urakawa

Received: 16 November 2020

Accepted: 13 February 2021

Published: 22 February 2021

Publisher's Note: MDPI stays neutral with regard to jurisdictional claims in published maps and institutional affiliations.

Copyright: (C) 2021 by the authors Licensee MDPI, Basel, Switzerland. This article is an open access article distributed under the terms and conditions of the Creative Commons Attribution (CC BY) license (https:/ / creativecommons.org/licenses/by/ $4.0 /)$.

\begin{abstract}
The accelerated and disordered growth of large urban centers has caused a significant loss of biodiversity and the negative effects are more significant in aquatic environments. Thus, the objective of this study is to assess the effects of environmental change due to urbanization in the abundance and biomass patterns of species belonging to the Zygoptera suborder. We tested the hypothesis that, in altered streams, there will be a predominance of organisms with fast growth and small biomass (r-strategists), and intermediate streams will have an overlapping of $\mathrm{r}$ and $\mathrm{k}$ strategists. In control streams, there will be a predominance of k-strategists, with slow growth, decreased abundance, and high biomass. Urban expansion in Amazonian streams will cause loss of Zygoptera species richness. Streams draining urban areas will have higher air temperatures than control streams. Thus, small-sized and less abundant species will be favored. We sampled 15 streams in the metropolitan area of Belém. Sites were classified, using the index of physical habitat integrity, as control, intermediate and altered. Comparisons between biomass and abundance were analyzed using W Statistics. Our analyses showed that: the effects of urbanization cause loss of k-strategists and favors r-strategists, once abundance was placed above biomass; in intermediate environments, contrary to what we expected, there was no overlapping of strategies, once r-strategists were also placed above k-strategists; in control environments, biomass was placed above abundance, suggesting these environments have a predominance of k-strategist species, as we suggested; and we observed increased levels of temperature favor the most abundant species, the ones having generalist biological mechanisms; however, contrary to what we expected, there was no difference in richness. With these results, we reinforce the need for public policies to create or maintain the riparian forest along streams running through urban areas and create or maintain urban parks.
\end{abstract}

Keywords: water pollution; aquatic insect community structure; biological traits; drangonflies

\section{Introduction}

Currently, 55\% of the world's population lives in urban areas, a proportion that might increase to $68 \%$ until 2050. Projections show that the gradual migration of the human population from rural to urban areas is congruent with the worldwide population growth, which could reach 2.5 billion until 2050 [1]. The most urban areas on the planet include North America (with $82 \%$ of urban population) followed by Latin America and the Caribbean [2]. Increased population growth in urban areas causes significant losses in the world's biodiversity $[3,4]$. Such damages can be more expressive in sensitive systems such as aquatic ecosystems, because they are strongly associated with the surrounding terrestrial vegetation. The loss of this vegetation can cause an increase in channel silting, homogenization of the substrate, water channeling and discharge of residential and/or industrial waste [5]. 
In this context, lotic systems (e.g., small streams) are highly dependent on the energy coming from the riparian forest, by entering allochthonous material such as leaves, branches, fruits, and trunks [6]. However, the removal of riparian forest changes the structure of communities depending on this system, which can cause local extinction of sensitive species and the entry of more generalist species due to the new conditions [7]. Although the Brazilian Amazon region is less populated than the rest of the country, it has several problems related to urban impacts, mainly in its two main urban centers: Belém and Manaus [8]. Once the metropolitan region of Belém has approximately 2.5 million inhabitants distributed throughout a territory of $6.890 \mathrm{~km}$ square, it has one the highest population densities among Brazilian capitals [9].

The region is rich in its hydrographic area, as it is surrounded by the Guajará Bay, cut by rivers, streams, canals, and having artificial lakes and lagoons [10]. This area has been gradually modified by disorganized urban expansion, which advances more and more in permanent protection areas [11]. For aquatic macroinvertebrates, these effects have affected the species' richness and abundance [11,12], as well as substitution and extinction of local species $[5,10,13]$. However, macroinvertebrates have been used as important tools to evaluate anthropogenic impacts in aquatic ecosystems [14].

Among the existing organisms, the Odonata community stands out as a bioindicator group, because odonates have a strong relationship with the water physical and physicochemical structure, as a result of this their richness, abundance and composition can be strongly affected by environmental change $[15,16]$. In addition, the group has been efficiently used to identify impacts on altered environments [16] and currently, endangered species are part of the catalog of IUCN and the Chico Mendes Institute for Biodiversity Conservation (ICMBIO) $[17,18]$. In the Amazon, the order Odonata has two suborders (Zygoptera and Anisoptera) that present idiosyncratic differences in ecophysiological requirements, which allows us to use them as bioindicators in different studies [19,20]. Mostly, Zygoptera has a higher frequency of occurrence in streams with high vegetation cover due to thermoregulation characteristics. Most are considered thermal conformers, generally, with small body size and high conductance (high exchange of body heat at room temperature), the body temperature varies with the environment, mainly due to heat exchange [21]. As a result, they live in more shaded areas close to water bodies $[7,19]$.

Other biotic factors, e.g., morphological variation [22], trait variation [23] and the effects in the abundance and/or growth [24] have also been used to measure environmental impacts. One of these methods is comparing the abundance/biomass proposed by Warwick et al. [25], known as the ABC (Abundance Biomass Comparison) curve. In stable environments, where disturbance is not frequent, the community is supposedly composed of k-strategist species (with slow growth, large body size and delay to reach the reproductive stage); these species are rarely numerically dominant, but are dominant in terms of biomass. Thus, the biomass curve extends above the abundance curve, classifying the environment as a control or less altered. For example, species of the genus Mnesarete and Hetaerina, which are prevalent in preserved environments, are not very abundant, but have a higher biomass than other genera of Zygoptera [7,26].

On the other hand, in altered environments, where the vegetation cover is low and anthropic disturbance is high, the community would be dominated by r-strategists. The abundance curve would be above the biomass curve. There would be a predominance of organism with low biomass, but quite abundant, for example, species from the genus Ischnura that are abundantly found in altered environments, but low in body biomass [27,28]. In environments where an intermediate disturbance occurs, the tendency is to have an overlap of the curve, as these environments support both dominant species in terms of biomass and abundance [26,29].

In our study, we assessed the effects of urbanization in the Zygoptera community in the Brazilian Amazon. For that, we tested the following hypotheses: (i) altered streams will have a predominance of organisms with fast growth and small biomass (r-strategists), in intermediate streams, $r$ and $k$-strategist species will overlap, once these environments 
tend to be ecologically stable; (ii) in control streams, there will be a dominance of kstrategists, with slow growth, less abundant and with high biomass; (iii) urban expansion in Amazonian streams will cause loss of Zygoptera species richness. Our premise is that the suppression of natural vegetation maximizes the incidence of light in the water bodies, increasing the temperature and changing the availability of resources (e.g., Wood residues inside and outside the channel, oviposition and perching sites) so that the organisms there tend to invest more in reproductive success than in body growth in favor of their offspring [30,31].

\section{Material and Methods}

\subsection{Study Area}

The study was carried out in the Metropolitan region of Belém (MRB), the State of Pará, comprising the municipalities of Belém, Ananindeua, Marituba, Benevides, Santa Bárbara and Santa Izabel. The MRB covers an area of $1827.7 \mathrm{~km}^{2}$, with a population of approximately 2.5 million habitants (almost a third of the population of the State of Pará). This region comprises the Guamá River basin, which has a similar profile to other Amazon regions, as it presents relief gradations varying between igapós, floodplains and Terra Firme forests, and are formed by holo-Pleistocene alluvial plains [10] (Figure 1).

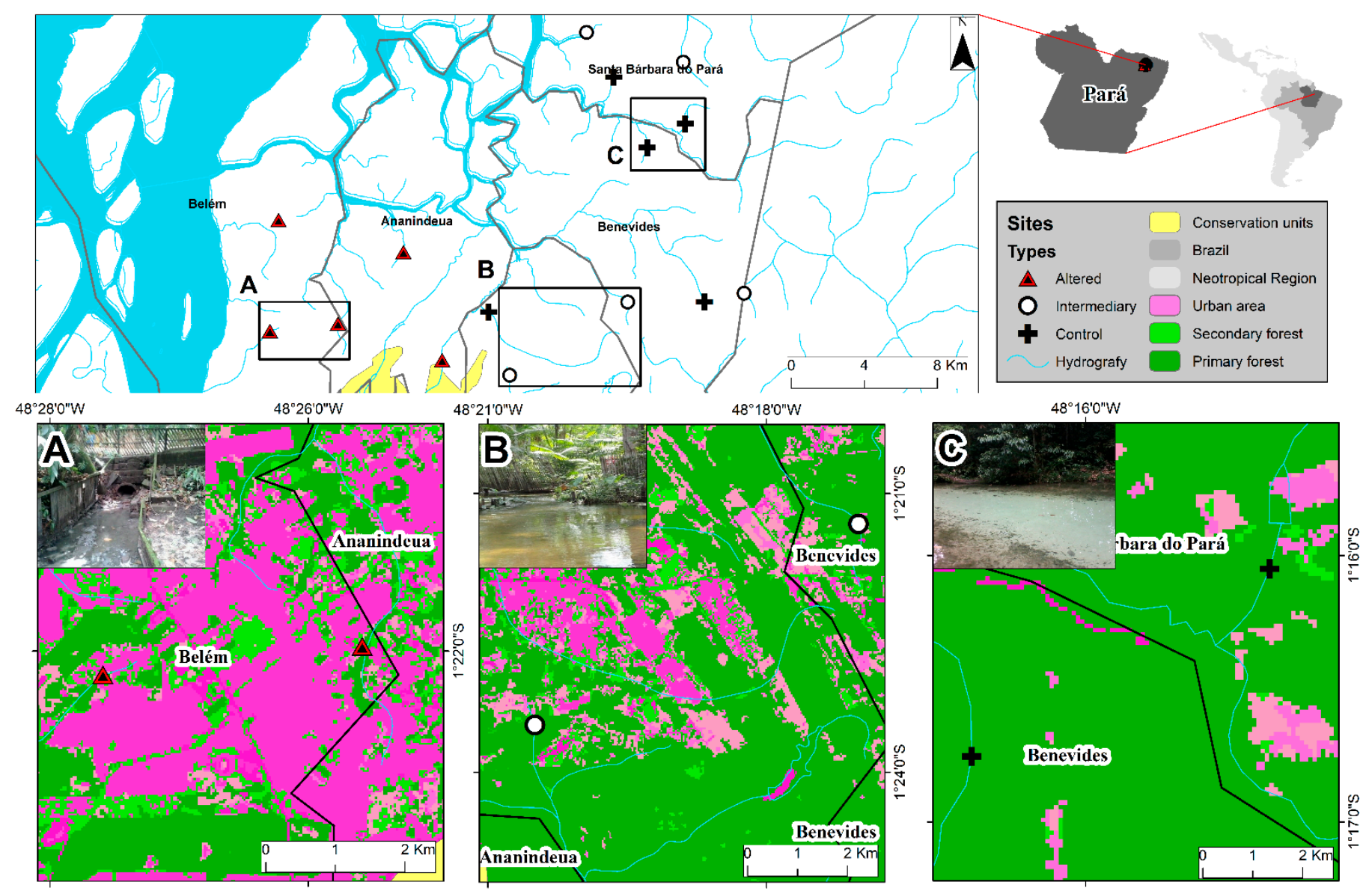

Figure 1. Drainage system of the metropolitan region of Belém and the distribution of the study streams, State of Pará, Brazil. The variation in color tones indicates the degree of occupation in the watershed, warmer colors (red tones) represent sites with a higher population density and greener tones represent areas with little modification and with a greater amount of remaining natural vegetation. (A) Altered, (B) Intermediate and (C) Control.

According to the Köppen classification, the region's climate falls into the "humid equatorial" category of the "Afi" type, with average annual precipitation of $2000 \mathrm{~mm}$ and a 
mean temperature of $35^{\circ} \mathrm{C}$. Rainfall extends from December to May, while the dry season (or less rainy season) goes from June to November. Regarding soil type, the Yellow Latosol predominates in the MRB, followed by the Concretionary Lateritic soil, Low humic Gleysol, Hydromorphic Podzol and Quartz Sand [32].

The streams selected in the Guamá river basin are small, with a mean width of $1.2 \mathrm{~m}$ and a mean depth of $0.8 \mathrm{~m}$, all first to third-order streams, according to the Strhaler classification. Urban streams suffer from disposal on untreated sewage, have no riparian forest and most of them are canalized. On the other hand, preserved streams, which we will call from now on 'control streams', are located inside parks surrounding Belém, with the presence of riparian forest and few or no human disturbance.

\subsection{Biological Sampling}

Samplings were performed in 15 streams with different environmental disturbance degrees, five from altered areas, five from the intermediate group and five from the control group. The streams selected were of small orders (first and second-order streams, according to Strahler's classification) with similar environmental conditions but with different degrees of environmental disturbance, for example, native vegetation cover and air temperature vary between treatments (see Section 2.3). Sampling was carried out during the dry season, from August to December 2014 and 2015. For the collection, we used a fixed-area scanning method that has already been efficiently applied to survey the Odonata assemblages in the Amazon [33]. In addition, this is the sampling protocol that was proposed for Odonata in a recent publication standardizing the methodology of Arthropod studies [34]. Adult specimens were collected along a fixed stretch of $100 \mathrm{~m}$ of each stream, divided into 20 segments of $5 \mathrm{~m}$, according to the best way to access sites to perform the collection. The survey methodology for the Odonata community is based on a fixed area scanning method already successfully used in other studies with this group $[12,15,16,35]$. To collect specimens, we used an entomological net with a $30 \mathrm{~cm}$ rim and the sampling effort of one collector. The average time spent at each sampling site was one hour. At the same time, we measured air temperature in shaded sites close to the water. The collections were performed between 10 am and $2 \mathrm{pm}$, a period in which sunlight reaches the streambed. These minimal conditions were necessary to assure that all Odonata groups (temperature conformers, heliotherms and endotherms) were active at the collection time [35]. Collected odonates were stored and preserved following the protocol described by Lencioni [36].

To identify the specimens, we used specialized taxonomic keys [36-41], and compared the specimens with the collection of the Zoology Museum at the Federal University of Pará, and, when necessary, we sent them to a specialist to confirm identification.

\subsection{Integrity Assessment of the Aquatic Environment}

To assess physical habitat integrity, we used the Habitat Integrity Index (HII), an index consisting of a 12-item questionnaire (for more information, see Supplementary Materials 1, applied to each sampled stream). We assessed the following characteristics: (i) access to the stream, (ii) width of the riparian forest; (iii) completeness of riparian forest; (iv) status of the riparian forest inside a 10-m stretch, (v) retention devices, (vi) channel structure, (vii) status of the stream flow, (viii) canopy openness, (ix) human physical occupation, (x) disposal of domestic and industrial waste, (xi) population density in $100 \mathrm{~m}$ and (xii) presence of waste disposal [11,33].

Each item has four to six alternatives ordered by scores to represent the increasing integrity of the systems. The calculated index is expressed numerically, scoring from 0 to 1 , where values close to one represent environments with high integrity levels. Based on the final scores, each stream was classified into three treatments (altered, intermediate and control). Streams with scores from 0 to 0.4 were considered altered, the ones from 0.4 to 0.7 were considered intermediate, and those with scores from 0.7 to 1 were considered control streams. These classification scores based on the HII have already been successfully used in other studies in the Amazon region [42]. Additionally, in a recent review, it was 
shown that the index is very efficient in studies of environmental monitoring using aquatic insects [43].

For our study, the results of the Habitat Integrity Index (HII) ranged from 0.03 to 0.9 . Streams between 0 to 0.3 were considered altered, streams with 0.3 to 0.6 were considered intermediate, whereas streams from 0.6 to 0.9 were considered control environments. In total, there were five streams for each group (Altered, intermediate and control) (Appendix A).

\subsection{Biomass Measurements}

We selected five male individuals from each species, and we measured total length, wing length, abdomen length, chest width, chest length and weight. To measure biomass, we used the average of the total weight divided by the average of the total size of each species; this was done to remove the effect of size in the measures [16]. We obtained the morphological measures only for male individuals due to the low abundance of females in the study area and the absence of taxonomic keys and/or guides for female specimens. This standardization also avoids differences associated with sexual dimorphism. The procedure was repeated three times to try diminishing measurement errors, in all the analyses, we used a mean value of the three measurements (for more information, see Supplementary Materials 2).

\subsection{Statistical Analyses}

To assess the sampling efficiency of Odonata species per site, we built an accumulation curve, with 1000 randomizations, based on the number of samples [44]. In the graph, we plotted the number of species observed (number of species observed in each stream) and the estimated species richness. Species richness was estimated using the non-parametric first order Jackknife resampling estimator [45], this method estimates the total richness summing observed richness (number of species collected) to a parameter calculated from the number of rare species. The estimate was calculated in the Estimates program (Statistical Estimation of Species Richness and Shared Species from Samples) version 7.5.0 [44]. To test the hypothesis that species richness differs in control, intermediate and altered environments, we performed a one-way ANOVA [46]. The assumptions of homogeneity and normal distribution were previously tested.

In order to compare the abundance and biomass among altered, intermediate and control streams, we used [25] abundance and biomass curve approach. For that, we used $\mathrm{W}$ statistics, which consists of a numerical summary of the ABC curve, with values varying from -1 (abundance curve over biomass curve) to 1 (biomass curve over abundance curve) and the abundance curves of ranked species and K-dominance, which allows us to extract information about the patterns of relative species abundances, without reducing this information to summary statistics, such as ecological indexes [24,47]. Unlike multivariate methods, these distributions can extract universal characteristics from the community structure, which are not a function of a specific rate, thus being able to be associated with different levels of biological stresses [16,24].

To test the hypothesis that Zygoptera individual abundance (the sum of all individuals in each sample unit) would be affected by air temperature, we performed a Pearson correlation and all normality tests were performed [46], to assess if species abundance (dependent variable) is correlated with temperature (independent variable). All analyses were performed in the $\mathrm{R}$ program, using the vegan package [48]. The significance value used in the analysis was $p<0.05$.

\section{Results}

We collected 342 specimens, of 45 observed species and $70 \pm 6.0$ (mean \pm confidence interval) total estimated richness by jackknife, with a sampling efficiency of $64 \%$ (observed/estimated) (Supplementary Materials 3). Considering only altered streams, we observed 32 species and obtained $38 \pm 5.75$ estimated species, with a sampling efficiency of $84 \%$. We observed 30 species for intermediate streams and obtained $42 \pm 8.14$ estimated 
species, with a sampling efficiency of $71 \%$. Control streams had 35 observed species and $49 \pm 8.6$ estimated species, with a sampling efficiency of $71 \%$. When analyzing the curve of richness estimates, there is stabilization, showing the effort exuded in the study was efficient to capture the diversity of the region (Figure 2).

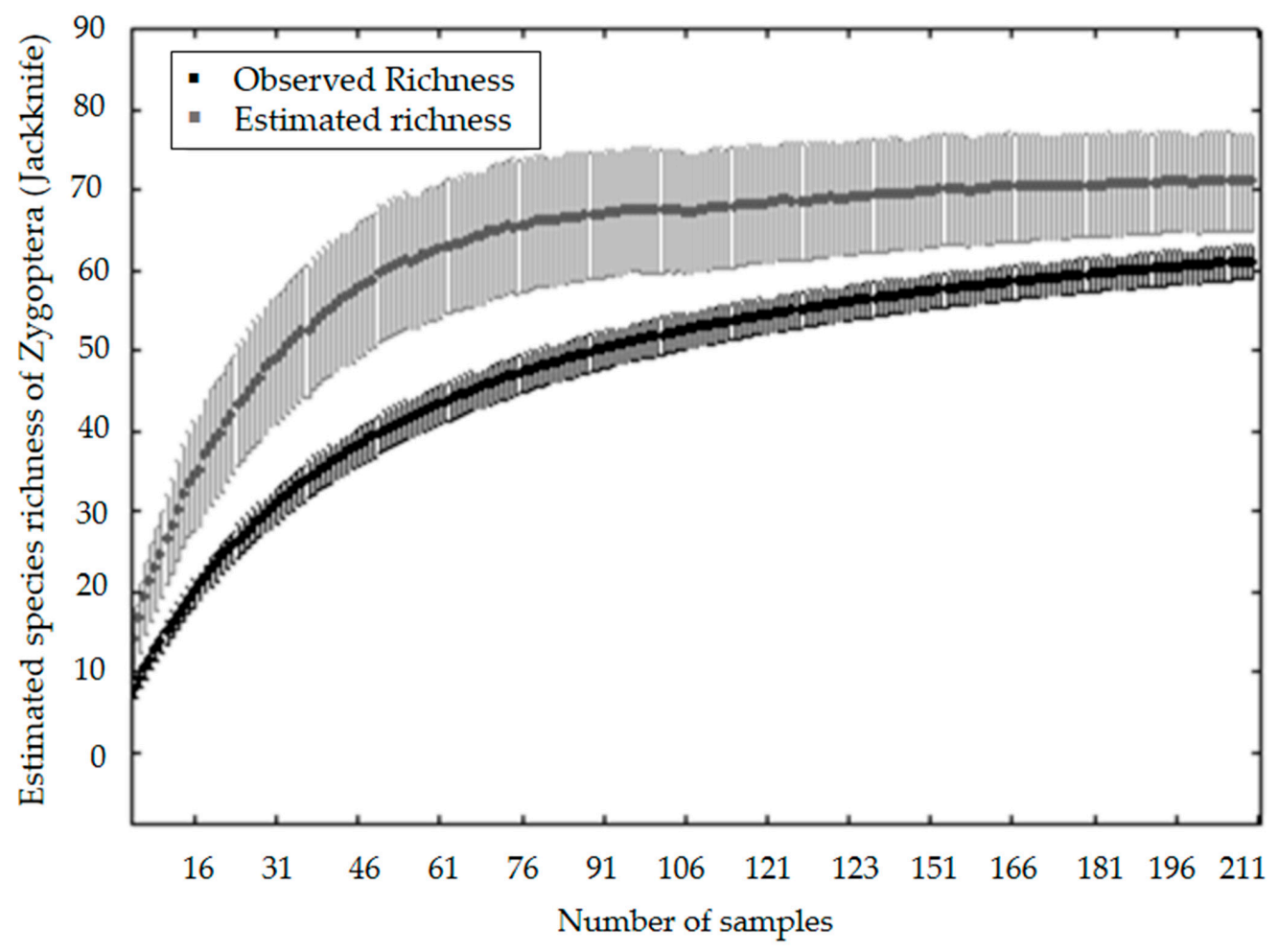

Figure 2. Estimated species richness of Zygoptera. Whiskers represent a 95\% confidence interval.

The most abundant families were Coenagrionidae $(n=284)$ and Calopterygidae $(n=42)$. The most abundant genera in altered streams were Acanthagrion, Argia and Ischnura. In intermediate streams, the most abundant were Neoneura, Epipleoneura and Argia. In control sites, the most abundant genera were Argia, Epipleoneura and Mnesarete. The most abundant species were Epipleoneura metálica Rácenis, $1955(n=32)$, Neoneura luzmarina De Marmels, 1989 ( $n=27)$, Acanthagrion aepiolum Tennessem, $2004(n=26)$, Argia indicatrix Calvert, $1902(n=25)$, Acanthagrion kennedii Williamson, $1916(n=24)$ and Argia fumigata Hagen in Selys, $1865(n=21)$ (Table 1). Our hypothesis that preserved areas would have increased richness was not corroborated (ANOVA: $\mathrm{F}=3.511 ; \mathrm{G} . \mathrm{L} .=12 ; p=0.062$ ). A similar result was found when the comparison was made using the species richness estimated by the jackknife, since the confidence interval of one group overlaps the mean of the other, indicating that there are no statistically significant differences (Figure 3).

When analyzing the $\mathrm{ABC}$ curve for each type of environment, in control areas the biomass curve was above the abundance $(w=0.094)$. In intermediate $(w=-0.129)$ and altered $(\mathrm{w}=-0.332)$ environments, the abundance was above biomass. Thus, our hypotheses were corroborated, once, in preserved environments, there was a predominance of less abundant individuals with high biomass. However, in intermediate and altered environments (influenced by urbanization), organisms with low biomass, but highly abundant, were predominant (Figure 4). 
Table 1. Number of individuals sampled in the Metropolitan Region of Belém, Pará (Brazil).

\begin{tabular}{|c|c|c|c|c|c|c|}
\hline \multirow[b]{2}{*}{ Suborder } & \multirow[b]{2}{*}{ Family } & \multirow[b]{2}{*}{ Species } & \multicolumn{3}{|c|}{$\begin{array}{c}\text { Number of Specimens } \\
\text { by Treatment }\end{array}$} & \multirow[b]{2}{*}{$\begin{array}{c}\text { Total } \\
\text { Specimens }\end{array}$} \\
\hline & & & Altered & Control & Intermediare & \\
\hline \multirow[t]{43}{*}{ Zygoptera } & Calopterygidae & Hetaerina sanguinea Selys, 1853 & 1 & 7 & 6 & 14 \\
\hline & & Hetaerina sp. & - & 1 & 4 & 5 \\
\hline & & Mnesarete aenea (Selys, 1853) & - & 3 & - & 3 \\
\hline & & Mnesarete smaragdina (Selys, 1869) & - & 4 & 1 & 5 \\
\hline & & Mnesarete sp. & - & 5 & 1 & 6 \\
\hline & & Mnesarete williamsoni Garrison, 2006 & - & 10 & - & 10 \\
\hline & Coenagrionidae & Acanthagrion aepiolum Tennessen, 2004 & 26 & - & - & 26 \\
\hline & & Acanthagrion amazonicum Sjöstedt, 1918 & 9 & - & - & 9 \\
\hline & & Acanthagrion kennedii Williamson, 1916 & 14 & 4 & 6 & 24 \\
\hline & & Acanthagrion rubrifrons Leonard, 1977 & 3 & 2 & - & 3 \\
\hline & & Acanthagrion sp. & 4 & - & - & 4 \\
\hline & & Aeolagrion dorsale (Burmeister, 1839) & 1 & 2 & 6 & 9 \\
\hline & & Argia fumigata Hagen in Selys, 1865 & - & 16 & 5 & 21 \\
\hline & & Argia indicatrix Calvert, 1902 & 21 & - & 4 & 25 \\
\hline & & Argia oculata Hagen in Selys, 1865 & - & 7 & 3 & 10 \\
\hline & & Argia sp. & 2 & 3 & 1 & 6 \\
\hline & & Argia sp.1 & - & 1 & - & 1 \\
\hline & & Argia thespis Hagen in Selys, 1865 & 3 & 2 & 1 & 6 \\
\hline & & Argia tinctipennis Selys, 1865 & - & 5 & 4 & 9 \\
\hline & & Ischnura capreolus (Hagen, 1861) & 5 & - & - & 5 \\
\hline & & Ischnura sp. & 9 & - & - & 9 \\
\hline & Dicteriadidae & Heliocharis amazona Selys, 1853 & - & 1 & - & 1 \\
\hline & Lestidae & Lestes sp. & 1 & - & 1 & 2 \\
\hline & Megapodagrionidae & Heteragrion icterops Selys, 1862 & - & 1 & - & 1 \\
\hline & & Oxystigma williamsoni Geijskes, 1976 & - & 3 & - & 3 \\
\hline & Polythoridae & Chalcopteryx radians Ris, 1914 & - & - & 3 & 3 \\
\hline & & Chalcopteryx rutilans (Rambur, 1842) & - & 3 & - & 3 \\
\hline & & Chalcopteryx sp. & - & 1 & - & 1 \\
\hline & Protoneuridae & Epipleoneura kaxuriana Machado, 1985 & - & 4 & 3 & 7 \\
\hline & & Epipleoneura lamina Williamson, 1915 & - & - & 8 & 8 \\
\hline & & Epipleoneura metallica Rácenis, 1955 & - & 21 & 11 & 32 \\
\hline & & Epipleoneura solitaria De Marmels, 1989 & - & 8 & 1 & 9 \\
\hline & & Epipleoneura sp. & 1 & 1 & 2 & 4 \\
\hline & & Epipleoneura spatulata Rácenis, 1960 & - & - & 5 & 5 \\
\hline & & Neoneura fulvicollis Selys, 1886 & - & - & 1 & 1 \\
\hline & & Neoneura gaida Racenis, 1953 & 1 & - & 6 & 7 \\
\hline & & Neoneura luzmarina De Marmels, 1989 & - & 11 & 16 & 27 \\
\hline & & Neoneura sp. & - & - & 2 & 2 \\
\hline & & Neoneura rubriventris Selys, 1860 & - & 1 & 1 & 2 \\
\hline & & Protoneura scintilla Gloyd, 1939 & 1 & - & - & 1 \\
\hline & & Protoneura sp. & 1 & 1 & 2 & 4 \\
\hline & & Protoneura tenuis Selys, 1860 & - & 4 & 3 & 7 \\
\hline & & Total specimens & 103 & 130 & 107 & 340 \\
\hline
\end{tabular}




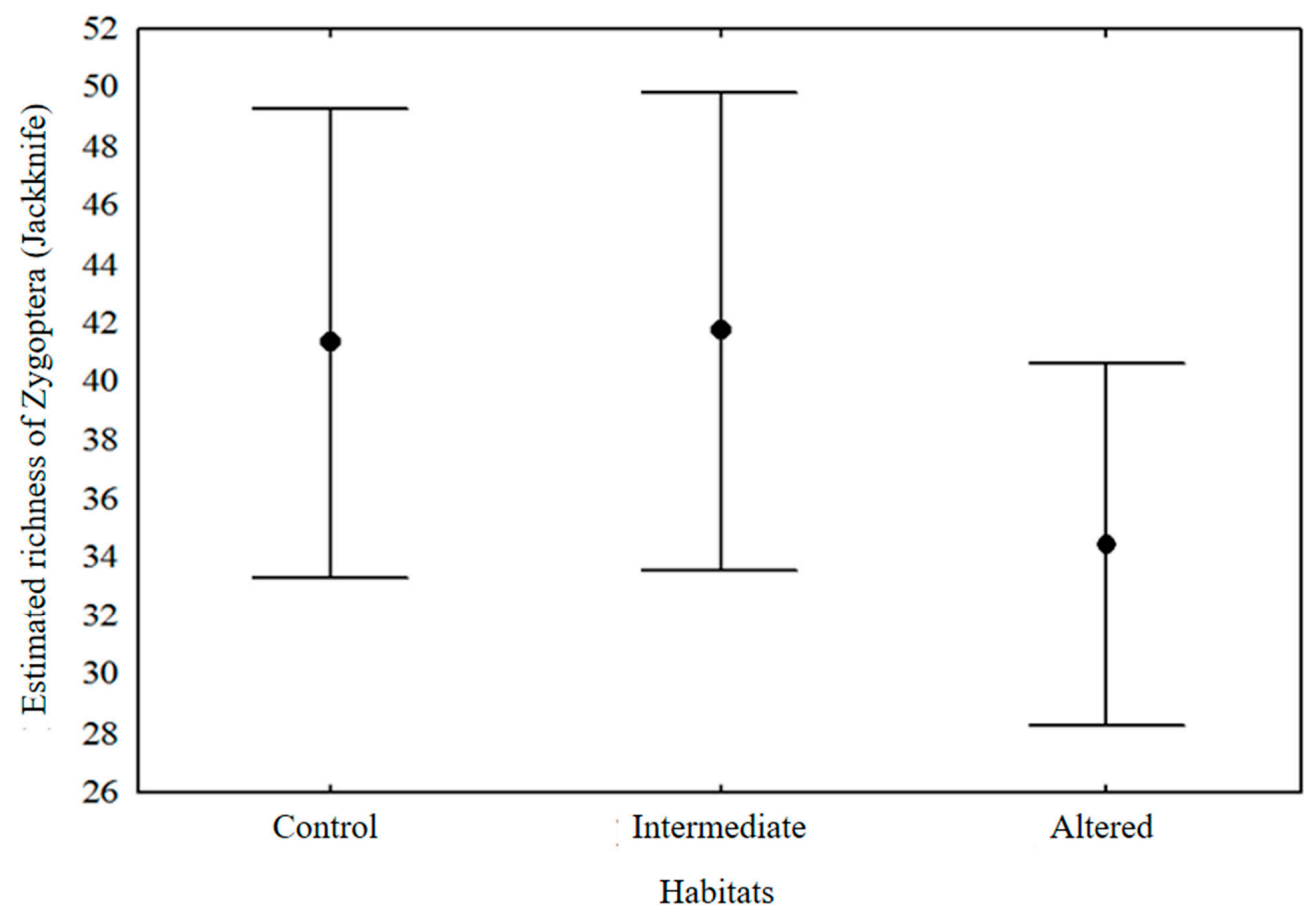

Figure 3. Estimated species richness of Zygoptera by Jackknife procedure, distributed according to conservation level (altered, intermediate and control). Bars represent a confidence interval of $95 \%$.

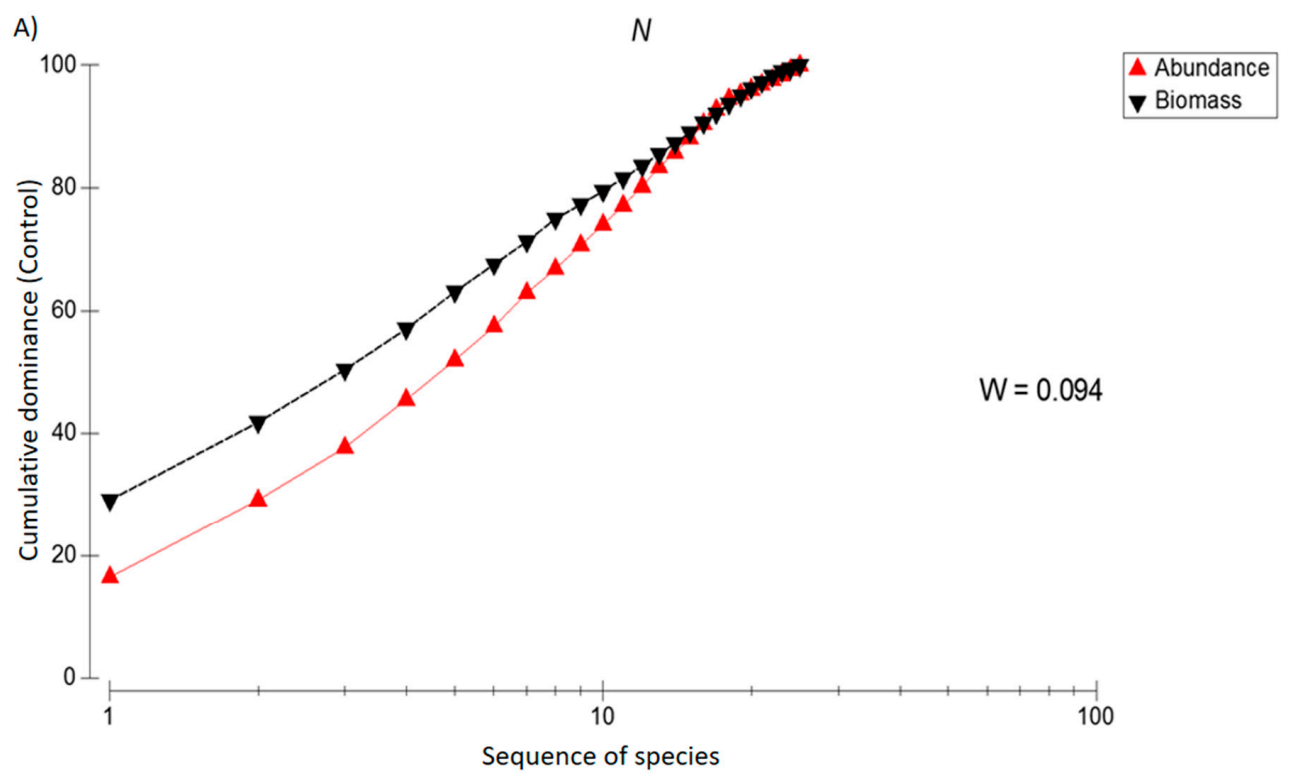

Figure 4. Cont. 

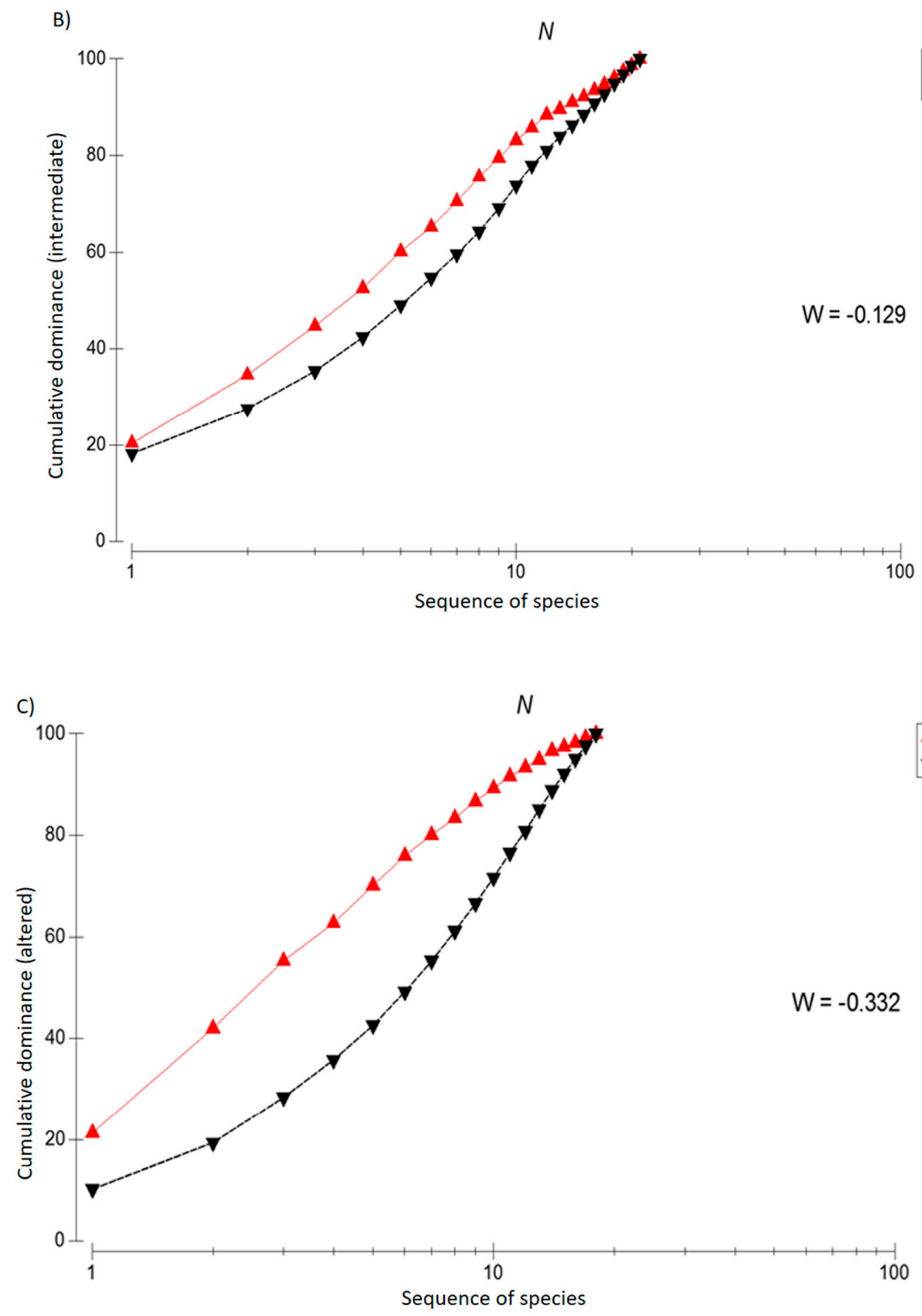

Figure 4. Abundance (red triangles) and Biomass (black triangles) curve of species from the Zygoptera suborder. (A) Total suborder were sampled in control streams; (B) Total suborder were sampled in intermediate streams; (C) Total suborder were sampled in altered streams.

The hypothesis that air temperature would be a significant predictor for the Odonata order, since it would affect species abundance, was corroborated $\left(\mathrm{r}^{2}=0.35 ; p=0.019\right)$. There was a positive relationship between the abundance of individuals and air temperature, suggesting an increase in temperature increases species abundance (Figure 5). The correlation explained $35 \%$ of the variation found in the data. 


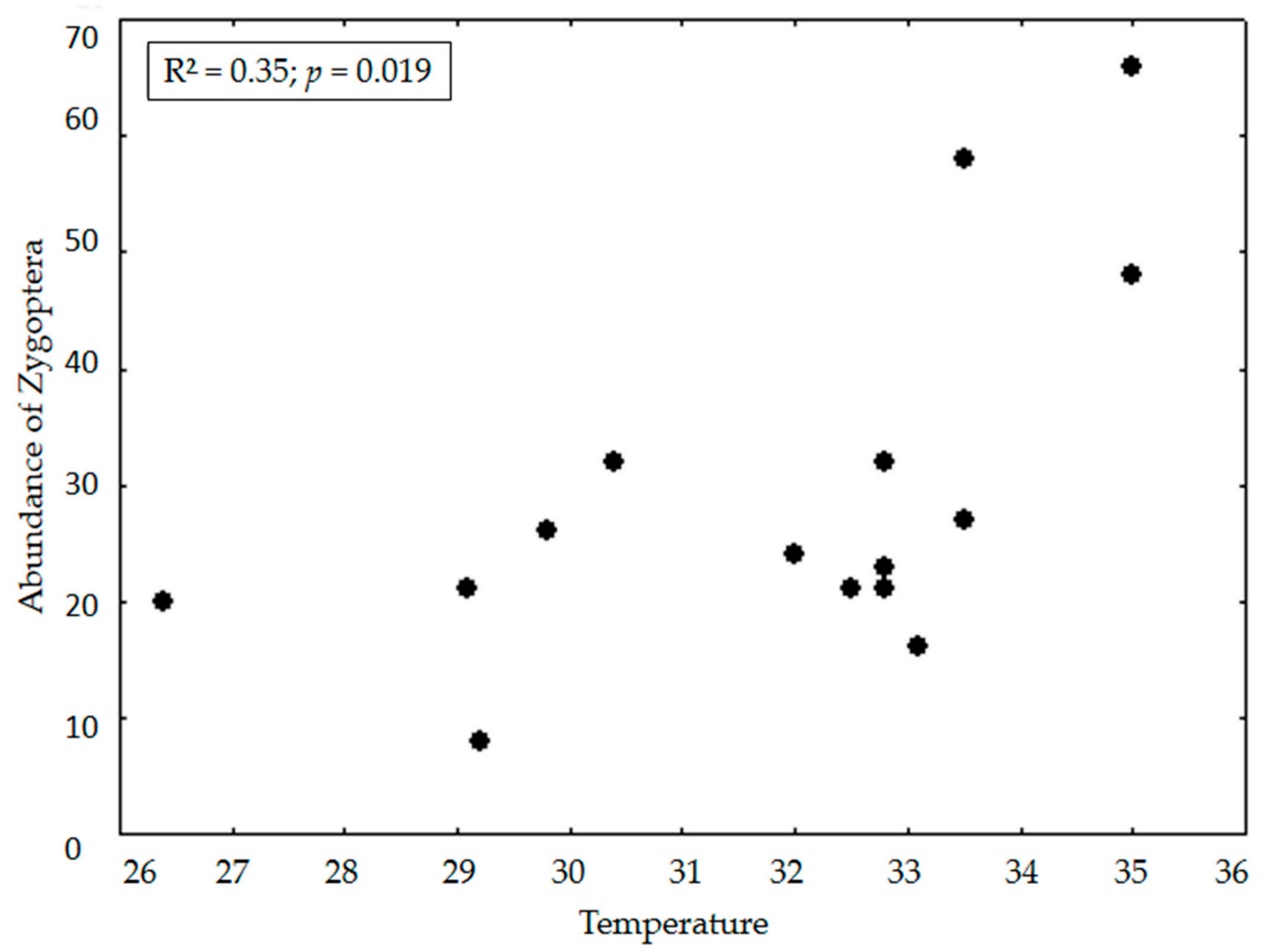

Figure 5. Pearson Correlation between specimens' abundance and air temperature, in streams sampled in Belém, State of Pará, Brazil.

\section{Discussion}

Our results accumulate evidence that urbanization negatively affects Amazonian streams, in accordance with previous studies $[4,10]$. As we expected, biomass was higher than abundance in preserved environments, and abundance was higher than biomass in altered environments. Contrary to what we expected, the hypothesis that in intermediate streams, there would be an overlapping of $r$ and $k$-strategists was not corroborated, once intermediate streams have shown a predominance of abundant species. Suggesting that, in these environments, the Odonata community is numerically dominated by organisms with r-strategy tendencies. This study has similar result similar with what was registered in the Brazilian Cerrado, where species with small body size were dominant in altered environments, reflecting the effects of anthropogenic change in streams [41]. On the other hand, following the patterns we expected, the abundance was positively affected by temperature, suggesting environments with increased temperature favor the most abundant Zygoptera species [49]. However, species richness of Zygoptera was not affected by urbanization, contrary to what we expected evidence that, depending on the type of land use, the morphological characteristics of Odonata may better respond to the effects of environmental changes. However, our study found no significant changes in species richness between treatments, but it is possible to observe a loss in species richness in altered environments. However, there was great variation within the treatments. For this reason, we indicate that new studies try to increase the number of samples of each type of habitat to try to reduce this variation. In general, here we can show that the Odonata community is very sensitive to changes in the environment, therefore, corroborate the idea that the Order's organisms are a good bioindicators to monitor the effects of urban expansion.

For example, in this study, the ABC curve revealed changes in altered environments due to the departure of k-strategist species and the entry of r-strategist species [47]. However, the substitution mechanism might have been one of the main reasons there was no change in species richness. Thus, we reinforce the importance of using multiple response 
metrics in studies assessing human impact, to avoid possible noise in classical metrics, such as species richness. Once, in conditions of land use change, the loss of species restricted to pristine environments in favor of more generalist species that can adapt to different environmental conditions is recurrent [50]. Productivity processes in streams might have influenced the responses of this study since environmental productivity may be an important factor in structuring communities [51]. Indeed, there is a positive relationship between highly productive environments (usable resources) and increased abundance of Odonata species [52]. Thus, as time passes, the excess of resources might cause eutrophication in streams and, in response, there will be a loss of abundance of organisms due to competitive exclusion [53]. It is important to emphasize the necessity of performing long-term studies to detect these possible changes in the Odonata community as time passes [54]. For example, Gonçalves \& Braga [55] reported increased fish abundance in altered and highly productive environments. In another study with fish evaluating biotic integrity in a tidal inlet in estuarine areas, the curves showed that the estuarine environment is moderately disturbed.

In intermediate and altered environments of our study, we found a substitution of specialist species of pristine environments, that cannot stand human change (e.g., riparian forest removal, effluent discharge, canopy openness and siltation) [5,11]. For example, species from the Mnesarete genus were one of the most representative in control environments. Individuals of this genus have a large body size if compared to other zygopterans. Generally, they inhabit forests, have limited dispersal, and live most of the time in perches [56]. Thus, they have a positive relationship with the riparian forest, due to the necessities and restrictions of thermoregulation and reproduction $[7,57,58]$.

Contrarily, urbanization favors species with characteristics more similar to r-strategists, e.g., the Acanthagrion genus, the most abundant genus, followed by Ischnura. Both genera live well in lentic environments, with little oxygen and high temperatures, characteristics common to streams altered due to the removal of the riparian forest and construction of barriers and/or channels. According to Fulan et al. [59], immatures of these genera do not tolerate low temperatures, their ideal temperature is between $25^{\circ} \mathrm{C}$ and $28{ }^{\circ} \mathrm{C}$ degrees, thus, adults of these genera tend to oviposit in warm waters. Moreover, species from the Ischnura genus have a short life cycle, a common characteristic of r-strategists $[54,57,60]$.

Several streams in the metropolitan region of Belém, especially the ones found in the central area, are the most affected by domestic waste, which causes strong impacts in the odonate community. However, streams more distant from the center are the ones that suffer less with human impact, precisely because we found in these environments species with high biomass, the ones that need pristine environments to forage, copulate and oviposit, and have their ecophysiological requirements more restricted to the temperature. MonteiroJunior et al. [11] found similar results in a study in Manaus, in which specialist Zygoptera species were extinguished from urban environments (with increased temperature) and with alterations in the water, due to human change.

Certainly, our results also indicate the importance of parks inside the metropolitan region of Belém, which were used as control areas in this study. It was possible to verify the parks are managing to support most forest specialist species, reinforcing the importance of creating or maintaining parks that pervade large urban centers. Once the total loss of local species or scarcity in the variability of species can directly result in loss of ecosystem services, humans depend [58]. However, it was possible to detect a concerning scenario, since intermediate streams, the ones with little human influence, are not supporting forest specialist species, suggesting unorganized urban growth is already affecting streams suffering indirect effects of urbanization.

Thus, we conclude that the diversity of streams draining the metropolitan region of Belém were affected by urbanization. Specialist taxa were locally extinguished from altered environments because they were intolerant to removing the riparian forest (increased temperature) and water pollution. Hence, it is necessary to implement management measures to reduce impact and recover areas of permanent protection inside urban areas. Further- 
more, we reinforce the necessity to maintain and create parks inside big urban centers to preserve forest species. Finally, we suggest Odonata should be used as bioindicators in monitoring urban impacts, once they have shown to be sensitive to changes caused by this type of land use.

Supplementary Materials: The following are available online at https:/ / www.mdpi.com/2673-413 $3 / 2 / 1 / 8 / s 1$.

Author Contributions: Conceptualization, J.P.B.; F.G.C., and L.J.; methodology, J.P.B.; software, F.G.C.; validation, F.G.C. and L.J.; formal analysis, J.P.B. and F.G.C.; investigation, J.P.B.; data curation, F.G.C.; writing-original draft preparation, J.P.B.; writing-review and editing, F.G.C., and L.J.; visualization, L.J.; supervision, L.J. All authors have read and agreed to the published version of the manuscript.

Funding: This research received no external funding.

Acknowledgments: We are very grateful to Bruna Moreira, Michela Borges, Aline Leão Ylana Cavalcante and Rafael Dias for their assistance during field expeditions. We are also grateful to the Brazilian National Council for Scientific and Technological Development (CNPq) for granting research productivity fellowships to LJ (304710/2019-9) and a postdoc scholarship to FGC (88887.358247/201900). Finally, we thank Pró-Reitoria de Pesquisa e Pós-graduação / Universidade Federal do Pará for financing the English review of the manuscript. This article was the result of scientific initiation by J.P.F.

Conflicts of Interest: The authors declare no conflict of interest.

\section{Appendix A}

Table A1. Classifications of streams in urban areas and control based on HII sampled in the Metropolitan Region of Belém, Pará (Brazil).

\begin{tabular}{cccc}
\hline $\mathbf{N}$ & Groups & Streams & HII \\
\hline 1 & Altered & Parques dos Igarapés & 0.133 \\
2 & Altered & Apeti & 0.175 \\
3 & Altered & Águas Brancas & 0.172 \\
4 & Altered & Paraíso dos Reis & 0.275 \\
5 & Altered & Tenoné & 0.291 \\
6 & Intermediate & Sítio Uruana & 0.508 \\
7 & Intermediate & Muicuiambá & 0.536 \\
8 & Intermediate & Pau D'Arco & 0.537 \\
9 & Intermediate & Paar & 0.541 \\
10 & Intermediate & Igarapé Neópolis & 0.68 \\
11 & Control & Igarapé Coreia & 0.773 \\
12 & Control & Cupuaçu & 0.715 \\
13 & Control & Paricatuba & 0.743 \\
14 & Control & Macumba & 0.812 \\
15 & Control & Santa Maria & 0.941 \\
\hline
\end{tabular}

\section{References}

1. United Nations. World Urbanization Prospects: The 2018 Revision (ST/ESA/SER.A/420); Department of Economic and Social Affairs, Population Division: New York, NY, USA, 2019.

2. De Long, D.C.J. Defining Biodiversity. Wildl. Soc. Bull. 1996, 24, 738-749.

3. Walpole, M.; Almond, R.E.A.; Besançon, C.; Butchart, S.H.M.; Campbell-Lendrum, D.; Carr, G.M.; Collen, B.; Collette, L.; Davidson, N.C.; Dulloo, E.; et al. Tracking Progress Toward the 2010 Biodiversity Target and Beyond. Science 2009, 325, $1503-1504$. [CrossRef]

4. Butchart, S.H.M.; Walpole, M.; Collen, B.; Van Strien, A.; Scharlemann, J.P.W.; Almond, R.E.A.; Baillie, J.E.M.; Bomhard, B.; Brown, C.; Bruno, J.; et al. Global Biodiversity: Indicators of Recent Declines. Science 2010, 328, 1164-1168. [CrossRef]

5. Monteiro-Júnior, C.D.S.M.; Juen, L.; Hamada, N. Analysis of urban impacts on aquatic habitats in the central Amazon basin: Adult odonates as bioindicators of environmental quality. Ecol. Indic. 2015, 48, 303-311. [CrossRef] 
6. Gordon, N.D.; McMahon, T.A.; Finlayson, B.L.; Gippel, C.J.; Nathan, R.J. Stream Hydrology: An Introduction for Ecologists, 2nd ed.; Wiley: Hoboken, NJ, USA, 1995.

7. Carvalho, F.G.; Roque, F.D.O.; Barbosa, L.; Montag, L.F.D.A.; Juen, L. Oil palm plantation is not a suitable environment for most forest specialist species of Odonata in Amazonia. Anim. Conserv. 2018, 21, 526-533. [CrossRef]

8. Barthem, R.B.; Da Costa, M.C.; Cassemiro, F.; Leite, R.G.; Da Silva, N.J. Diversity and Abundance of Fish Larvae Drifting in the Madeira River, Amazon Basin: Sampling Methods Comparison. Biodivers. Dyn. Balance Planet 2014, 2014, 137-158. [CrossRef]

9. IBGE-Instituto Brasileiro de Geografia e Estatística, IBGE Discloses Municipal Population Estimates for 2019: Social Statistics. Available online: https:/ /agenciadenoticias.ibge.gov.br/en/agencia-press-room/2185-news-agency/releases-en/25283-ibgedivulga-as-estimativas-da-populacao-dos-municipios-para-202 (accessed on 29 August 2019).

10. Siqueira, G.W.; Aprile, F. Avaliação de risco ambiental por contaminação metálica e material orgânico em sedimentos da bacia do Rio Aurá, Região metropolitana de Belém-PA. Acta Amaz. 2013, 43, 53-64. [CrossRef]

11. Monteiro-Júnior, C.; Juen, L.; Hamada, N. Effects of urbanization on stream habitats and associated adult dragonfly and damselfly communities in central Brazilian Amazonia. Landsc. Urban Plan. 2014, 127, 28-40. [CrossRef]

12. Monteiro-Júnior, C.D.S.M.; Couceiro, S.R.M.; Hamada, N.; Juen, L. Effect of vegetation removal for road building on richness and composition of Odonata communities in Amazonia, Brazil. Int. J. Odonatol. 2013, 16, 135-144. [CrossRef]

13. Couceiro, S.R.; Hamada, N.; Forsberg, B.R.; Pimentel, T.P.; Luz, S.L.B. A macro invertebrate multimetric index to evaluate the biological condition of streams in the Central Amazon region of Brazil. Ecol. Indics 2012, 18, 118-125. [CrossRef]

14. Moreyra, A.K.; Padovesi-Fonseca, C. Environmental effects and urban impacts on aquatic macroinvertebrates in a stream of central Brazilian Cerrado. Sustain. Water Resour. Manag. 2015, 1, 125-136. [CrossRef]

15. Valente-Neto, F.; Roque, F.D.O.; Rodrigues, M.E.; Juen, L.; Swan, C.M. Toward a practical use of Neotropical odonates as bioindicators: Testing congruence across taxonomic resolution and life stages. Ecol. Indic. 2016, 61, 952-959. [CrossRef]

16. Carvalho, F.G.; Pinto, N.S.; Júnior, J.M.B.D.O.; Juen, L. Effects of marginal vegetation removal on Odonata communities. Acta Limnol. Bras. 2013, 25, 10-18. [CrossRef]

17. IUCN 2020, The IUCN Red List of Threatened Species. Available online: https:/ / www.iucnredlist.org (accessed on 3 May 2020).

18. Oliveira, L.F. (Ed.) Livro Vermelho da Fauna Brasileira Ameaçada de Extinção; ICMBio/MMA: Sao Paulo, Brazil, 2018.

19. Oliveira-Junior, J.M.B.; Juen, L. The Zygoptera/Anisoptera Ratio (Insecta: Odonata): A New Tool for Habitat Alterations Assessment in Amazonian Streams. Neotrop. Entomol. 2019, 48, 552-560. [CrossRef]

20. Bastos, R.C.; Brasil, L.S.; Oliveira-Junior, J.M.B.; Carvalho, F.G.; Lennox, G.D.; Barlow, J.; Juen, L. Morphological and phylogenetic factors structure the distribution of damselfly and dragonfly species (Odonata) along an environmental gradient in Amazonian streams. Ecol. Indic. 2021, 122. [CrossRef]

21. De Marco, P., Jr.; Latini, A.O.; Resende, D.C. Thermoregulatory constraints on behavior: Patterns in a Neotropical dragonfly assemblage. Neotrop. Entomol. 2005, 34, 155-162. [CrossRef]

22. Reis, E.F.; Pinto, N.S.; Carvalho, F.G.; Juen, L. Efeito da integridade ambiental sobre a Assimetria Flutuante em Erythrodiplax basalis (Libellulidae: Odonata)(Kirby). EntomoBrasilis 2011, 4, 103-107. [CrossRef]

23. Pereira, D.F.; de Oliveira, J.M., Jr.; Juen, L. Environmental changes promote larger species of Odonata (Insecta) in Amazonian streams. Ecol. Indic. 2019, 98, 179-192. [CrossRef]

24. Yemane, D.; Field, J.G.; Leslie, R.W. Exploring the effects of fishing on fish assemblages using Abundance Biomass Comparison (ABC) curves. ICES J. Mar. Sci. 2005, 62, 374-379. [CrossRef]

25. Warwick, R.M.; Clarke, K.R. Relearning the ABC: Taxonomic changes and abundance/biomass relationships in disturbed benthic communities. Mar. Biol. 1994, 118, 739-744. [CrossRef]

26. De Marco, P., Jr.; Batista, J.D.; Cabette, H.S.R. Community Assembly of Adult Odonates in Tropical Streams: An Ecophysiological Hypothesis. PLoS ONE 2015, 10, e0123023. [CrossRef]

27. Juen, L.; De Oliveira-Junior, J.M.B.; Shimano, Y.; Mendes, T.P.; Cabette, H.S.R. Composição e riqueza de Odonata (Insecta) em riachos com diferentes níveis de conservação em um ecótone Cerrado-Floresta Amazônica. Acta Amaz. 2014, 44, $223-233$. [CrossRef]

28. Dutra, S.; De Marco, P. Bionomic differences in odonates and their influence on the efficiency of indicator species of environmental quality. Ecol. Indic. 2015, 49, 132-142. [CrossRef]

29. Calvão, L.B.; Juen, L.; de Oliveira, J.M.B., Jr.; Batista, J.D.; De Marco Júnior, P. Land use modifies Odonata diversity in streams of the Brazilian Cerrado. J. Insect Conserv. 2018, 22, 675-685. [CrossRef]

30. Nogueira, D.S.; Montag, L.; Nogueira, D.S.; Calvão, L.B.; Fogaça, L.; Montag, D.A. Little effects of reduced-impact logging on insect communities in eastern Amazonia Little effects of reduced-impact logging on insect communities. Environ. Monit. Assess. 2016. [CrossRef]

31. Oliveira-Junior, J.M.B.; De Marco, P.; Dias-silva, K.; Pereira, R.; Gontijo, C.; Santos, P.; Allan, T.; Hughes, R.M.; Juen, L. Limnologica Effects of human disturbance and riparian conditions on Odonata (Insecta) assemblages in eastern Amazon basin streams. Limnologica 2017, 66, 31-39. [CrossRef]

32. Embrapa-Empresa Brasileira de Pesquisa Agropecuária, Sistema Brasileiro de Classificação de Solos. Available online: https: / / www.embrapa.br/solos/sibcs (accessed on 29 August 2020).

33. Nessimian, J.L.; Venticinque, E.M.; Zuanon, J.; De Marco, P.; Gordo, M.; Fidelis, L.; D’arc Batista, J.; Juen, L. Land use, habitat integrity, and aquatic insect assemblages in Central Amazonian streams. Hydrobiologia 2008, 614, 117-131. [CrossRef] 
34. Cezário, R.R.; Firme, P.P.; Pestana, G.C.; Vilela, D.S.; Juen, L.; Cordero-Rivera, A.; Guillermo, R. Sampling Methods for Dragonflies and Damselflies. Meas. Arthropod Biodivers. 2020, 2020, 223-240.

35. Mccauley, S.J.; Davis, C.J.; Relyea, R.A.; Yurewicz, K.L.; Skelly, D.K.; Werner, E.E. Metacommunity patterns in larval odonates. Oecologia 2008, 158, 329-342. [CrossRef] [PubMed]

36. Lencioni, F.A.A. Damselflies of Brazil: An Illustrated Identification Guide: II-Coenagrionidae Families; NHBS: São Paulo, Brazil, 2006.

37. Belle, J.A. synopsis of the species of Phyllocycla Calvert, with descriptions of four new taxa and a key to the genera of neotropical Gomphidae (Odonata, Gomphidae). Tijdschr. Voor Entomol. 1988, 131, 73-102.

38. Belle, J. Higher classification of the South-American Gomphidae (Odonata). Zool. Meded. 1996, 70, $297-324$.

39. Garrison, R. A Synopsis of the Genera Mnerasete Cowley, Bryoplathanon Gen. Nov., and Ormenoplebia Gen. Nov. (Odonata: Calopterygidae). Geography 2006, 2006, 90421531.

40. Pessacq, P. Synopsis of Epipleoneura (Zygoptera, Coenagrionidae, "Protoneuridae"), with emphasis on its Brazilian species. Zootaxa 2014, 3872, 201. [CrossRef]

41. Heckman, C.W. Encyclopedia of South American Aquatic Insects: Odonata-Anisoptera: Illustrated Keys to Known Families, Genera, and Species in South America; Springer: Berlin, Germany, 2006.

42. Mendes, T.P.; Oliveira-Junior, J.M.B.; Cabette, H.S.R.; Batista, J.D.; Juen, L. Congruence and the Biomonitoring of Aquatic Ecosystems: Are Odonate Larvae or Adults the Most Effective for the Evaluation of Impacts. Neotrop. Entomol. 2017, 46, 631-641. [CrossRef]

43. Brasil, L.S.; Luiza-Andrade, A.; Calvão, L.B.; Dias-Silva, K.; Faria, A.P.J.; Shimano, Y.; Oliveira-Junior, J.M.B.; Cardoso, M.N.; Juen, L. Aquatic insects and their environmental predictors: A scientometric study focused on environmental monitoring in lotic environmental. Environ. Monit. Assess. 2020, 192. [CrossRef]

44. Colwell, R.K.; Mao, C.X.; Chang, J. Interpolation, extrapolation, and comparingincidence-based species accumulation curves. Ecology 2004, 85, 17-27. [CrossRef]

45. Chao, A.; Chiu, C.H. Nonparametric Estimation and Comparison of Species Richness. eLS 2016, 2016, 1-11. [CrossRef]

46. Zar, J.H. Biostatistical Analysis, 5th ed.; Pearson: London, UK, 2010.

47. Carvalho, F.G.; Oliveira-Junior, J.M.B.; Farias, A.P.J.; Juen, L. Use of the ABC curve as a method to detect the effect of anthropogenic change on the Odonata (Insecta) assembly. Interciencia 2013, 38, 516-522.

48. Oksanen, J.; Blanchett, F.G.; Kindt, R.; Legendre, P.; Minchin, P.R.; O’Hara, R.B.; Simpson, G.L.; Solymos, P. Vegan: Community Ecology Package. R Package 2.0.3. Available online: http//CRAN.R-project.org/package=vega2013 (accessed on 29 August 2020).

49. Alves-Martins, F.; Brasil, L.S.; Juen, L.; De Marco, P.; Stropp, J.; Hortal, J. Metacommunity patterns of Amazonian Odonata: The role of environmental gradients and major rivers. PeerJ 2019, 2019. [CrossRef] [PubMed]

50. Heino, J. Environmental heterogeneity, dispersal mode, and co-occurrence in stream macroinvertebrates. Ecol. Evol. 2013, 3, 344-355. [CrossRef]

51. Balvanera, P.; Pfisterer, A.B.; Buchmann, N.; He, J.S.; Nakashizuka, T.; Raffaelli, D.; Schmid, B. Quantifying the evidence for biodiversity effects on ecosystem functioning and services. Ecol. Lett. 2006, 9, 1146-1156. [CrossRef]

52. Nagy, L.; Williams, W.; Tauxe, L.; Muxworthy, A.R.; Ferreira, I. Thermomagnetic recording fidelity of nanometer-sized iron and implications for planetary magnetism. Proc. Natl. Acad. Sci. USA 2019, 116, 1984-1991. [CrossRef]

53. Hooper, D.U.; Chapin, F.S.; Ewel, J.J.; Hector, A.; Inchausti, P.; Lavorel, S.; Lawton, J.H.; Lodge, D.M.; Loreau, M.; Naeem, S.; et al. Effects of biodiversity on ecosystem functioning: A consensus of current knowledge. Ecol. Monogr. 2005, 75, 3-35. [CrossRef]

54. Hassall, C.; Thompson, D.J.; French, G.C.; Harvey, I.F. Historical changes in the phenology of British Odonata are related to climate. Glob. Chang. Biol. 2007, 13, 933-941. [CrossRef]

55. Gonçalves, C.S.; Braga, F. Diversidade de peixes na área de influência da UHE Mogi Guaçu e lagoas marginais, bacia do alto Rio Paraná, São Paulo, Brasil. Biota Neotrop. 2008, 2, 103-114. [CrossRef]

56. De Marco, P., Jr.; Resende, D.C. Activity patterns and thermoregulation in a tropical dragonfly assemblage. Odonatologica 2002, 31, 129-138.

57. Chang, X.; Zhai, B.; Wang, M.; Wang, B. Relationship between exposure to an insecticide and fluctuating asymmetry in a damselfly (Odonata, Coenagrionidae). Hydrobiologia 2007, 586, 213-220. [CrossRef]

58. Tilman, D.; Reich, P.B.; Knops, J.M.H. Biodiversity and ecosystem stability in a decade-long grassland experiment. Nature 2006, 441, 629-632. [CrossRef]

59. Fulan, J.Â.; Henry, R. Distribuição temporal de imaturos de Odonata (Insecta) associados Eichhornia azurea (Kunth) na Lagoa do Camargo, Rio Paranapanema, São Paulo. Rev. Bras. Entomol. 2007, 51, 224-227. [CrossRef]

60. Gardner, T.A.; Barlow, J.; Chazdon, R.; Ewers, R.M.; Harvey, C.A.; Peres, C.A.; Sodhi, N.S. Prospects for tropical forest biodiversity in a human-modified world. Ecol. Lett. 2009, 12, 561-582. [CrossRef] [PubMed] 